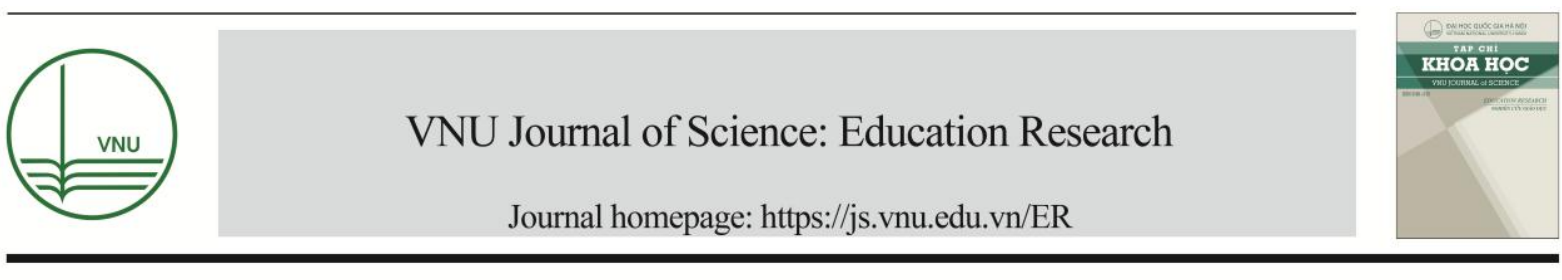

\title{
Improving the Vietnamese Accreditation in Light of the SACSCOC's Institutional Effectiveness Standards
}

\author{
Pham Thi Tuyet Nhung* \\ College of Foreign Languages - Hue University, \\ 57 Nguyen Khoa Chiem Street- Hue City, Vietnam
}

Received 07 August 2018

Revised 13 September 2018; Accepted 20 September 2018

\begin{abstract}
The purpose of this study was to explore Vietnamese educators' perspectives regarding the feasibility of implementing a U.S. Regional Accreditation standard ("Institutional Effectiveness") in the current Vietnamese higher education accreditation standards. An Institutional Effectiveness (IE) Process (Strategic Planning- IE Planning and AssessmentOperational Planning) and Assessment Cycle (Program Learning Outcomes-Curriculum MapAssessment Methods-Data Collection-Actions for Improvement) served as the conceptual framework for this study. The qualitative research design involved interviews with seven Vietnamese educators who work in centers for accreditation and offices of quality assurance in Vietnamese universities. Findings indicated that all participants supported the implementation of an IE standard and Assessment Cycle in Vietnamese higher education accreditation. Findings also stated that currently the IE Process and Assessment Cycle are not fully implemented in Vietnam higher education accreditation. The Vietnamese higher education institutions (HEIs) did not have a supportive culture of strategic planning due to centralized management by the Ministry of Education and Training (MOET). Moreover, most universities were only familiar with the first two steps in the Assessment Cycle. Based on the research findings, recommendations for the implementation of IE process and Assessment Cycle are made for MOET, Centers for Accreditation and Vietnamese HEIs.
\end{abstract}

Keywords: Vietnamese Higher Education Accreditation, Institutional Effectiveness, U.S. Regional Accreditation, outcome assessment, accountability and transparency.

\section{Introduction: Vietnamese higher education accreditation}

For the past 20 years, Vietnamese higher education has experienced many changes such as the development of continuing education and the movement toward massification. The

\footnotetext{
*Tel.: 18064518300.

Email: nhungptt48@gmail.com

https://doi.org/10.25073/2588-1159/vnuer.4164
}

universities and colleges have diversified to include public, nonprofit, private for-profit, and the first foreign owned university in Vietnam, the Royal Melbourne Institute of Technology (RMIT) (Hayden \& Lam, 2010) [1]. The number of HEIs has quadrupled since the 1980s with more than 400 colleges and universities (Pham, 2014) [2]. This rapid growth and diversification has led to concerns regarding quality; therefore, Vietnam chose to develop an 
accreditation system to improve the quality of higher education.

The development of accreditation in Vietnam dates back to the 2000 National Workshop on Quality Assurance in Higher Education held in Dalat (Nguyen, Oliver, \& Priddy, 2009) [3]. After organizing many international and national conferences to discuss a suitable model for accreditation development in Vietnam and conducting many research studies on international accreditation, Vietnam decided to use the U.S. accreditation model as a reference. Self-study and peer review have become key elements for the accreditation processes in Vietnam. In 2004, Vietnam issued its quality standards, which included 10 standards and 53 criteria covering all activities of higher education. Each criterion comprised two levels of achievement. This set of standards was issued just at the right time, when Vietnam higher education had moved from elite education toward massification (Nguyen, Thi Khanh Trinh, 2013) [4]. Forty universities participated in a pilot study, and in 2007, a final revised set of 10 standards and 61 criteria was established. This set of standards has assisted Vietnamese higher education institutions (HEIs) to conduct their self-studies with the aim of being more transparent to students and stakeholders (Nguyen, Oliver, \& Priddy, 2009) [3]. Vietnam higher education accreditation planned to implement Asian University Network - Quality Assurance (AUNQA) in 2018.

During its accreditation development in 2003, the Ministry of Education and Training (MOET) established both the General Department of Education Testing and Accreditation (GDETA) to issue accreditation policies and guidance to sustain national accreditation activities, and the centers for accreditation to award the accreditation certificates for HEIs. Subsequently, most HEIs established offices of quality assurance to comply with the national accreditation requirement (Nguyen, Evers and Marshall, 2017) [5]. During the more than 10-year implementation, accreditation has attracted much HEI involvement in the quality assurance process (CEA, 2014) [6] and raised academics' awareness about the role of quality assurance in the sustainability of higher education (Nguyen, Duc Chinh, 2013) [7].

However, most Vietnamese academics shared concerns that the current set of standards do not enhance the quality of higher education and do not address the key features of accreditation. Continuous quality improvement is missing (Do, 2013 [8]; Le \& Sai, 2013 [9]; Nguyen, 2013; Vo, 2013) [10], and the standards still focus on input and processes rather than output (Nguyen, 2009 [3]; Nguyen, 2013[4]; Nguyen et al., 2017)[5]. Meanwhile the current trend in U.S. and other countries' accreditation is to focus on output to improve the quality impact on HEIs (Nguyen et al., 2009) [3]. Therefore, this study examined Vietnamese key educators' perceptions about the potential of implementing a U.S. regional accreditation output standard, Institutional Effectiveness (IE), to shift the focus of Vietnam higher education accreditation standards from input and processes to output.

\section{U.S. Regional Accreditation and Institutional Effectiveness (IE)}

The U.S. has a more than 100-year-old history in accreditation. The development of accreditation in the U.S. has been greatly affected by the Higher Education Act (HEA), which has pushed accreditation standards from an input to an output focus. IE is one of the typical output standards in U.S. regional accreditation. IE provides information on how well an institution achieves its missions and strategic goals - output (Suskie, 2009) [11]. The purpose of IE is to enhance accountability, and the accreditation process is the primary method for assuring IE (Eaton, 2007) [12]. IE has five fundamental responsibilities: meet stakeholder needs; ensure the institution's health and well-being; ensure resources are effectively deployed, serve the public good; and 
demonstrate the institution's quality and effectiveness in fulfilling these responsibilities (Suskie, 2015) [13]. According to Suskie (2009) [11], assessment of student learning is a major component of IE because student learning is a central mission of HEIs.

In response to federal mandates, accreditation commissions have included measurements of IE into accreditation standards for many years. In 1989, SACSCOC was one of the first to use the term IE (Gaston, 2014) [14]. Overall, IE standards in the six regional accrediting agencies require institutions to show evidence that the institution and programs are achieving student learning outcomes and are using systematic and ongoing evaluation to refine key processes for student learning improvement.

\section{U.S. Accreditation Practices and Outcome Assessment}

Assessment efforts in higher education responded to external forces such as legislative and accrediting bodies asking for better evidence of accountability (Banta, 2004 [15]; Anderson, Anaya \& Bird, 2005) [16] and for demonstration of return on investment (Ewell, 2009) [17]. The aim of outcomes assessment is to improve learning, inform teaching, and articulate for stakeholders (students, parents, employers, and others) what students are achieving at an institution of higher education (Prochnow, 2011) [18]. Consequently, each program needs to describe what its graduates are able to do (outcomes) and to show evidence of assessment methods to demonstrate students' abilities (assessment).

\section{Conceptual framework: Institutional effectiveness (IE) process and assessment cycle}

This research used the IE process from SACSCOC, one of the highest demanding accreditation commissions in U.S. as a research conceptual framework. This process is trained for all institutions in SACSCOC area to demonstrate the transparent and accountable evidence of student learning. To comply with IE standards, institutions need to evaluate the effectiveness of educational programs, administrative support, and educational support. This research only focused on the effectiveness of educational programs. Figure 1 provides a graphic illustration of the IE process.

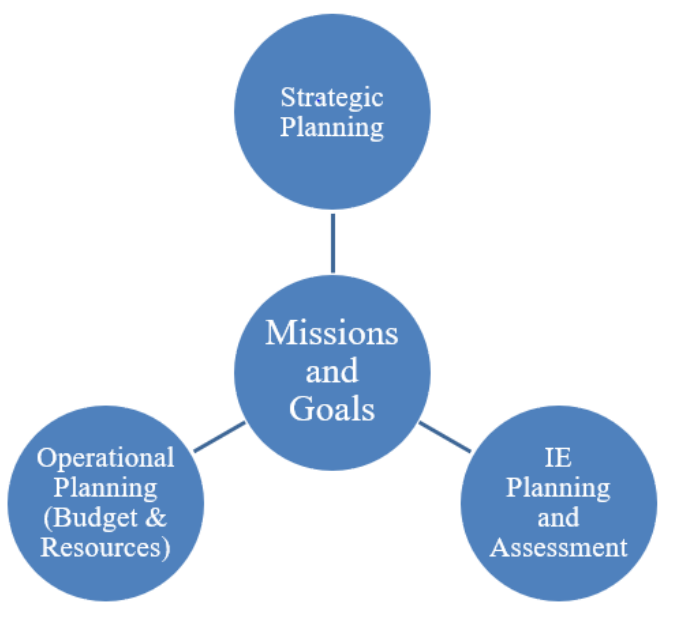

Figure 1. Institutional effectiveness model (Suskie, 2009 [11]; Hoefer, 2015) [19]. 
The IE process is structured around use of the Assessment Cycle (Figure 2) and IE reporting forms. Making changes for improvement or closing the loop, is the most important part of the Assessment Cycle.

\section{Methodology}

The goal of this study was to explore Vietnamese educators' perceptions regarding the feasibility and impact of implementing IE, with a focus on the effectiveness of educational programs in Vietnam's higher education accreditation. Therefore, a qualitative approach was the most appropriate method for collecting and analyzing data related to educators' perspectives about the specific phenomenon of interest.

Three questions guided this study:

1. What do Vietnamese educators think about Vietnam's current higher education accreditation standards?
2. What do Vietnamese educators think about implementation of the IE process and Assessment Cycle for educational programs in Vietnam's higher education accreditation?

3. What are educators' suggestions for adapting the IE process and Assessment Cycle for use in the Vietnamese higher education accreditation?

\section{Participants}

The seven representative Vietnamese educators were divided into two groups: administrators working in offices of quality assurance and accreditation in Vietnamese national universities and key educator experts who had been engaged in Vietnam accreditation from the beginning and had done much educational research in accreditation (Table 1). The interviews were conducted via Skype in Vietnamese.

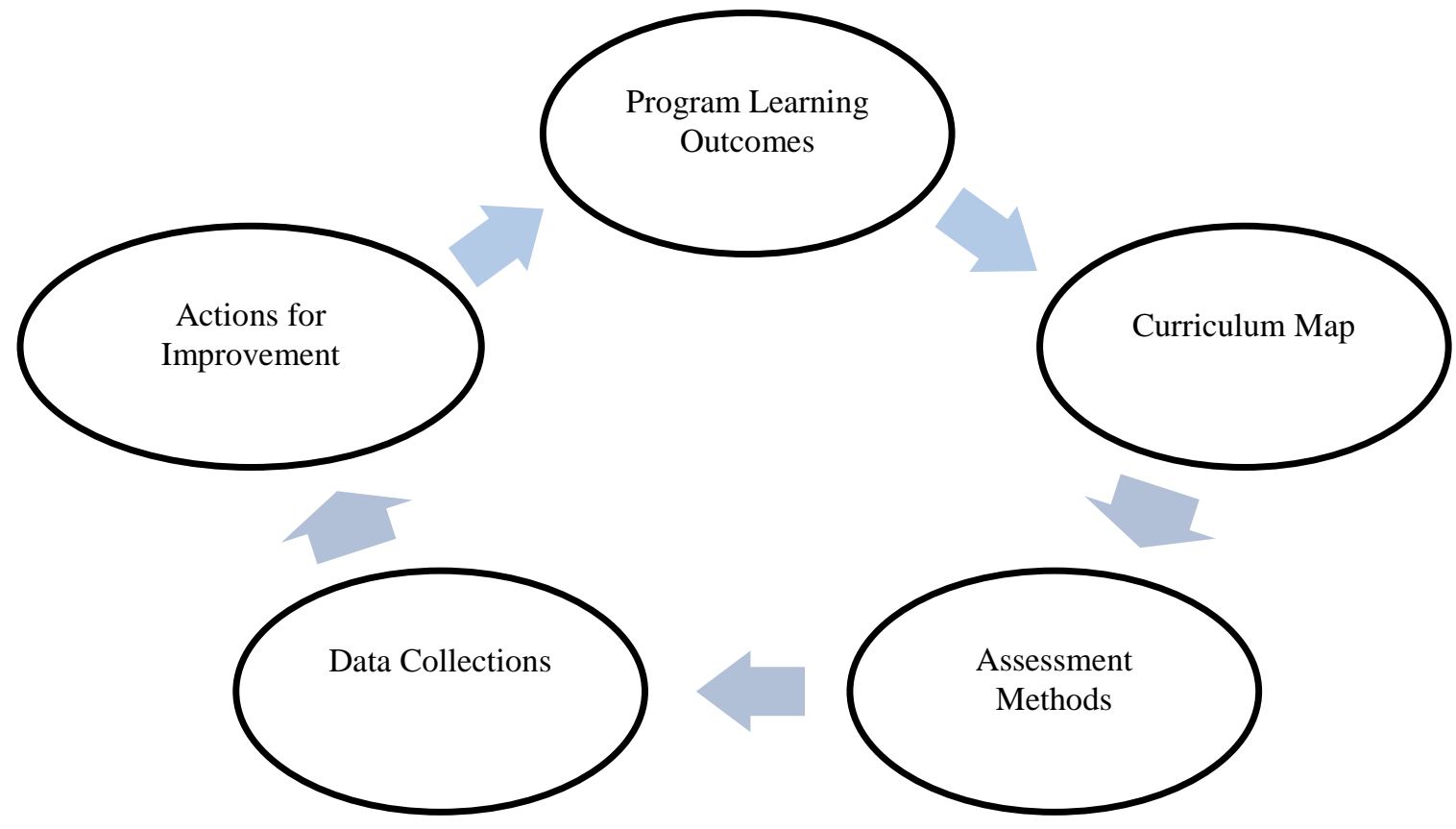

Figure 2. Assessment Cycle (Allen, 2004 [20]; Suskie, 2009) [11]. 
Table 1. Vietnamese Participants

\begin{tabular}{lll}
\hline No & Participant pseudonym & Position \\
\hline & Educator A & Former Director - MOET Center for Testing and Accreditation \\
& Educator B & Former President - Vietnam National University (VNU) \\
& Educator C & Former Director, VNU Center for Educational Accreditation \\
& Educator D & Former Director - Scholarship Granting Organization \\
Educator E & Director - Office of Quality Assurance \\
Educator F & Vice Director - Institution of Educational Research \\
Educator G & Director - VNU Center for Accreditation \\
\hline
\end{tabular}

\section{Data collection and analysis}

Semi-structured interviews (Appendix A), using a protocol of questions and additional probing questions based on information provided by the participant (Glesne, 2011 [21]; Merriam, 1998) [22], served to explore the Vietnamese educators' perceptions. Most of the sub-questions in the semi-structured interviews for the second research question followed steps in the IE process and Assessment Cycle.

I contacted participants by email to request their participation in the research study. Upon receiving their agreement to be interviewed, I provided the interview questions and requested a time and date for the interview. An informed consent form was signed, and I asked for permission to record the interview for later transcription and retrieval. Also, I kept an interview log (Merriam, 1998) [22] with specific information such as date, time, place, my impressions and reflections during the interview in a computer file.

Thematic and content analysis, synthesizing the common themes into categories, and patterns of frequently used words (Grbich, 2013) [23] were used for interview transcripts. Also, all themes related to the second research question were structured using steps in the IE process and Assessment Cycle. The process of analyzing data from the participants' interviews involved transcribing, coding, and interpreting the data. All the steps from writing the transcriptions to the data analysis were done in Vietnamese. After the data were completely analyzed and put into themes, I translated the themes and illustrative quotes into English for the research report.

\subsection{Research findings and discussion}

Participants' Perceptions about Vietnamese Higher Education Accreditation Standards

All participants agreed that the current set of Vietnamese accreditation standards lacks an outcomes standard. Educator C complained that institutional accreditation, especially the academic program standard, does not have a positive impact on the quality of the institution or student learning. Educator $\mathrm{C}$ explained that Vietnamese institutions do not state their missions: "Institutions just follow the requirements of the Ministry of Education and Training because MOET is the center." The absence of a mission statement in most institutions in Vietnam is a consequence of MOET's centralized management. Educator F emphasized that "the set of quality assurance standards in Vietnam does not have a standard addressing specifically the student learning outcomes."

Four participants indicated that the current standards are mostly about input, although some standards address process. Educator B said outcomes standards in the current set of quality assurance standards are insufficient. $\mathrm{He}$ commented that some criteria address the assessment of outcomes in the academic program standard, but not learning outcomes. $\mathrm{He}$ argued that the criteria for program learning outcomes simply called for evidence of institutional input, not institutional outcomes. $\mathrm{He}$ confirmed that there were no outcomes 
standards in the current set of quality assurance standards. Educator B supported the inclusion of an outcome standard like IE, as this would contribute to institutional quality enhancement.

Educator D also stated that the set of quality assurance standards focused more on input than outcomes.

"If the reports are full of numbers, they are not perfect. It would be an improvement if the standard requirements balance both qualitative (outcomes) and quantitative (input) information. Qualitative description and explanation enabled evaluators to get deeper information and facilitate their providing feedback. That would result in the accreditation process to be more beneficial to institutions."

When Educator E gave his opinion on the current set of quality assurance standards, he emphasized that the significant difference between the standards of Vietnam and the US is the approach.

"The Vietnamese approach is functionoriented, meanwhile [the] U.S. approach is objective and mission-oriented. In other words, the Vietnamese quality assurance standards focus on input and process, the U.S. standards focus on outcomes. As a result of the input and process-oriented standards, the Vietnamese standards tend to be very detailed because the standards have to cover all the functions of HEIs from students, faculty, administrator, infrastructure to library."

Educator E also explained the impact of culture on the development of quality assurance standards. The function-orientation in quality assurance represents the culture of small counties; therefore, the management style focuses on the content of activities rather than objectives. However, administrators focus on perfection of the process but do not relate the process to the destination. Educator $\mathrm{E}$ said, "They assume that the perfection of process will lead to the objectives, but it is not true."

The impact of functional management explains why the Vietnamese set of quality assurance standards include many detailed standards and criteria (10 standards and 61 criteria). Educator E also argued that "many educators complained that this set of quality assurance standards does not fit all types of institutions in Vietnam." Educator C emphasized that when institutions develop their mission statements and objectives, this will lead to changes in all their activities. Educator C agreed that Vietnam should change its approach to an objective-orientation because this approach is very beneficial to quality enhancement.

Educator $\mathrm{E}$ acknowledged that most developed countries produce evidence of quality through stakeholder satisfaction or the impact of students' knowledge on society, such as scholarly science research or community service. This type of evidence is typically the result of an objective-oriented approach. Educator E supported embedding outcome standards into the current set of quality assurance standards in higher education, but was concerned that it would take time for Vietnam to follow this trend.

Educator $\mathrm{G}$ made a comment that the set of quality assurance standards had a positive impact on the institutions' awareness of the significance of a mission statement. He explained,

"Public institutions do not have the culture to state the missions because they just do what the MOET tells them to do. They do not care about missions. However, the private institutions acknowledge the importance of mission statements toward their existence."

As an example, Educator $\mathrm{G}$ described his own onsite visit experience. The team had a difficult time locating the institution's mission statement; therefore, the team placed the institution on probation because the team did not accept the institution's claim that the mission was stated in their annual report. $\mathrm{He}$ declared that "because institutions do not align their missions and objectives to their daily activities, they had a feeling they were compared with the peers during the accreditation process." Educator G meant that the mission of research institutions should be 
different from that of the comprehensive university; however, Vietnam HEIs currently are not classified in this way.

The findings indicated that most participants supported implementation of an outcome standard in Vietnam higher education accreditation. Noticeably, most participants mentioned the Vietnamese function-oriented versus the U.S. objective-oriented approach as a challenge in the accreditation process. It could be inferred from participant's opinions that the function-oriented approach hinders the quality assurance process of accreditation in Vietnam.

Participants' Perceptions about the Institutional Effectiveness Process

To understand the participants' perspectives regarding use of IE in Vietnam, at the beginning of the interviews, I presented the four stages of the IE compliance process (Missions and Goals, Strategic Planning, IE Planning and Assessment, Operational Planning) and asked for the participants' perspectives on each stage. All participants were aware of IE process and Assessment Cycle benefits and all were impressed with the last step in the IE process, using assessment results to allocate resources (Operational Planning) for continuous quality improvement. Some participants shared specific benefits such as having institutional autonomy to set goals and design assessment measures to achieve them (Educator A), improving the internal quality of higher education (Educator C) and taking advantage of the Assessment Cycle to improve student learning through the course level (Educator D).

However, all participants mentioned the challenge of institutions just following MOET's central management and instruction. The Vietnamese higher education institutions do not have autonomy, especially financial autonomy, to establish their own mission, and they have no experience with strategic planning (Educator $\mathrm{C}$ and F). Individual participants also shared other concerns. For example, Educator A thought that Vietnam does not have the human resources to work on IE. Educator C stated, "the steps in the IE process are very new and weak in Vietnam"; therefore, he was unsure if implementation would be feasible. Educator D also noted that IE innovation would need the leaders' support and recognition to be successful.

These findings imply that financial autonomy for higher education institutions would be needed to facilitate implementation of the IE process. Financial autonomy enables institutions to do strategic planning, the first step in IE process. This conclusion is supported by the results of a MOET pilot of financial autonomy that was carried out over the period, 2014-2017. The pilot included 23 institutions demonstrating quality improvements such as opening new academic programs that meet social needs, innovations in materials, and new pedagogy for advanced programs (VNU-HNCollege of Economics, 2017).

Participants' Perceptions about the Assessment Cycle

To provide evidence of student learning at the program level, the academic programs need to follow five steps:

1. Write student learning outcomes (SLOs)

2. Map the curriculum to align the course learning outcomes with program learning outcomes (Curriculum Map)

3. Select the appropriate assessment measures

4. Collect and analyze data

5. Use the assessment results for program improvement (Actions for Improvement)

All participants agreed that Vietnamese institutions are familiar with the first two steps (SLOs and Curriculum Map), but they do not have any experience with the last three steps (Assessment Measures, Data Collection, and Actions for Improvement). The findings indicated that not many institutions practice all the steps of the Assessment Cycle. Four educators (A, C, D and G) claimed that program assessment is a significant challenge in Vietnam. Most academic programs develop student learning outcomes without conducting surveys to involve stakeholders and that outcomes, once developed, are not assessed. In addition to a lack of knowledge about how to 
write program learning outcomes, Educator C emphasized that institutions are unable to construct curriculum maps and assessment measures (e.g., a rubric). There is not a culture of stating SLOs for programs and institutions (Educator G), although the MOET center of testing and accreditation provided training workshops for many institutions.

In contrast, three Educators $(\mathrm{B}, \mathrm{F}$ and $\mathrm{G})$ described the positive program assessment practices of some big universities in the South of Vietnam and universities committed to international programmatic accreditation. These institutions had strong leader support, a budget allocation, high faculty and staff participation, and dedication to following programmatic accreditation (Educator F); therefore, they were eager and committed to the assessment process. Educator $\mathrm{F}$ emphasized that most of these institutions conducted program assessment for their internal improvement. They reported the results to faculty and leaders about the institution's achievement. In addition, these institutions practiced the first two steps in program assessment to achieve international programmatic accreditation (AUN) (Educator $\mathrm{G})$ or they received assistance from international experts in writing learning outcomes and mapping the curriculum to the learning outcomes (Educator B).

The interviews revealed that most institutions have become familiar with the concept of SLOs, but only some institutions in the South of Vietnam have mapped the sequence of courses in an academic program (curriculum map). All participants agreed that curriculum mapping is a good way to visualize the alignment of courses with respect to curriculum and program goals before choosing appropriate assessment measures to collect data for quality improvement. It can be inferred that institutions wanting international accreditation might have a better understanding and better implementation of the Assessment Cycle.

Participants' Suggestions for Implementing Institutional Effectiveness Standards and Continuous Improvement
All participants supported the implementation of an IE standard in Vietnamese institutional accreditation, as it currently does not have any outcomes standards. In order to implement the IE process successfully, four participants (B, C, E and G) suggested that MOET focus on managing the quality of higher education through policy rather than micromanaging institutional activities. They called for MOET to give more autonomy to institutions, especially financial autonomy. The institutions would then have more flexibility to conduct strategic planning that is consistent with their mission or context. In addition, four participants recommended using accreditation as an effective tool to manage the quality of education. The participants appeared to support linking the MOET budget allocation to accreditation. Institutions would need to provide evidence of student learning to receive government funding. This alignment would provide extrinsic motivation for HEIs to comply with accreditation. Most importantly, MOET needs to take an action on an institution's accreditation status. If an institution fails to obtain accredited status, the institutions should not be able to receive funding. This strong ramification of failing accreditation would encourage institutions to take the accreditation process more seriously. Eventually, accreditation would become an authentic indicator of improved educational quality.

To implement the Assessment Cycle, participants recommended constructing detailed guidelines for each step. For example, step one should define terminology (e.g., goals and learning outcomes) and provide guidelines for writing measurable outcomes because these outcomes direct academic programs in the instruction provided and ensure students achieve the stated outcomes. Most participants were impressed with the term measurable because this qualifier narrows the scope of outcomes and goals set by institutions. A guidebook also would need to address fundamental knowledge about curriculum 
maps, assessment measures, data collection techniques and writing specific actions for improvement to facilitate assessment planning for the next year.

\subsection{Recommendations for Implementing IE in Vietnam Higher Education Accreditation}

Recommendations for MOET

As the education cost is higher and higher in U.S., there was a call for higher accountability and transparency in student learning from HEIs and all six U.S. regional accreditation commissions responded to this call by embedding an IE standard into their accreditation standards (Middaugh, 2007 [24]; Gaston, 2014) [14]. Therefore, in addition to encouraging more institutions to participate in the financial autonomy initiative to improve $\mathrm{HE}$ quality, MOET should consider emphasizing accountability in its current "three transparency policy". For example, Ewell (2009) [17] stated that U.S. regional accreditation commissions quickly included IE requirements in the standards when pressured by the Department of Education to evidence the quality of student learning. Vietnam can follow this practice to embed the IE process into Vietnamese Higher Education accreditation standards. Vietnamese MOET should develop a systematic structure for requiring evidence of student learning, which would call for public and private centers for accreditation to revise the standards to include student outcomes. In addition, MOET should consider an accountable and transparent policy requiring institutions to make available all information about their institutions, especially posting the evidence of student learning on their websites. Vietnam can learn from practices of the U.S. Voluntary System of Accountability Program (VSA): (a) provide a tool for public institutions to demonstrate accountability and transparency, particularly in the areas of access, cost, student progress, and student outcomes; (b) provide a consumer information tool with clear, consistent, and comparable information on the undergraduate student experience through the College Portrait website; and (c) support innovation in the measurement and reporting of educational outcomes and facilitate the identification and implementation of effective practices as part of institutional improvement efforts (VSA, 2016) [25]. MOET should consider adapting VSA practices that are relevant to the Vietnam context such as the evidence of student learning, College Portrait, and employment rate.

To facilitate implementation of the IE process, MOET should fund the assessment of student learning and use the results as performance indicators of the institutions' quality assurance. This funding support and use of indicators would encourage institutions to train for and adopt processes that respond to outcomes-oriented standards in Vietnam higher education accreditation.

Recommendations to Centers for Accreditation

Currently, Vietnam has four public and one private centers of accreditation. These centers are authorized to conduct onsite visits and provide training to HEIs. The research findings confirmed that institutional accreditation in Vietnam does not have an outcome standard; therefore, the centers for accreditation should consider proposing an outcome standard into the higher education accreditation standards. IE should be a separate standard in Vietnamese institutional accreditation. For example, SACSCOC has two standards addressing IE (Core Requirement 2.5 and Comprehensive Standard 3.3) that Vietnam could consider embedding into its current higher education accreditation standard.

"The institution engages in ongoing, integrated, and institution-wide research-based planning and evaluation processes that (1) incorporate a systematic review of institutional mission, goals, and outcomes; (2) result in continuing improvement in institutional quality; and (3) demonstrate the institution is effectively accomplishing its mission. (Institutional effectiveness)." (Core Requirement 2.5., SACSCOC, 2012, p. 18) 
"3.3.1 The institution identifies expected outcomes of educational programs, assesses the extent to which it achieves these outcomes, and provides evidence of improvement based on analysis of the results in each of the following areas: (Institutional Effectiveness)" (Comprehensive Standard 3.3.1, SACSCOC, 2012, p. 27)
A significant component of the SACSCOS IE Report is to show that assessment results are used to allocate resources and funding to support student learning. Additional components of the IE Report are displayed in Table 2.

Table 2. Description of the institutional effectiveness reporting form components

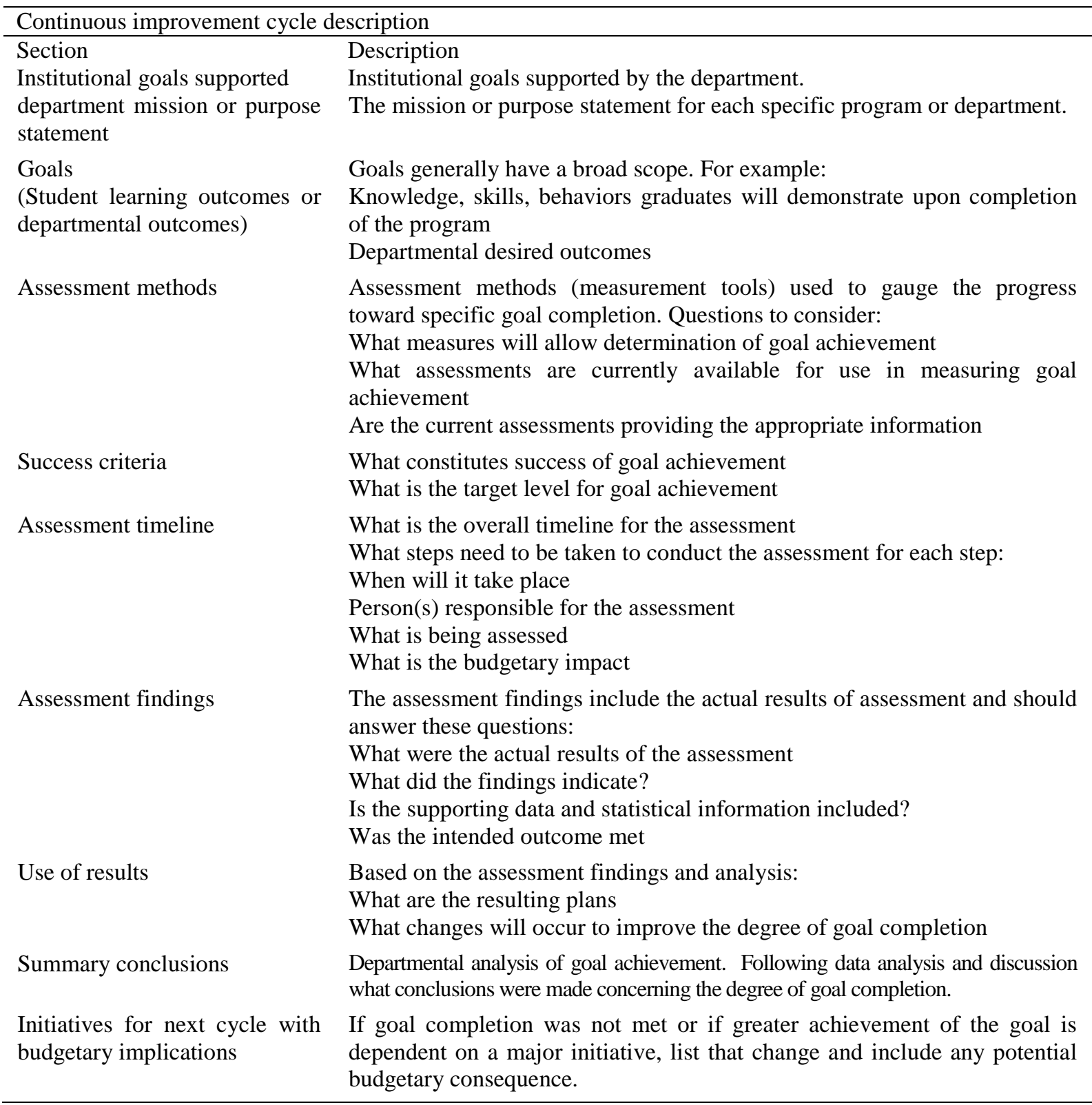

Note: Adapted from Hoefer (2015) [19]. The institutional effectiveness process. 
Recommendations to Vietnamese HEIs

Hoefer's (2015) [19] IE model (Figure 1) might be helpful for implementation of an IE standard at Vietnamese institutions. In the U.S., the IE office is typically a complete unit under the administrative office at each institution. Normally, the IE office reports directly to the vice president of academic affairs. The major responsibilities of this office are aligned closely with the IE cycle: develop assessment methodologies, coordinate the continuous improvement cycle, and oversee data collection. Some U.S. HEIs also have a vice president of IE who oversees academic affairs and institutional effectiveness for the entire university.

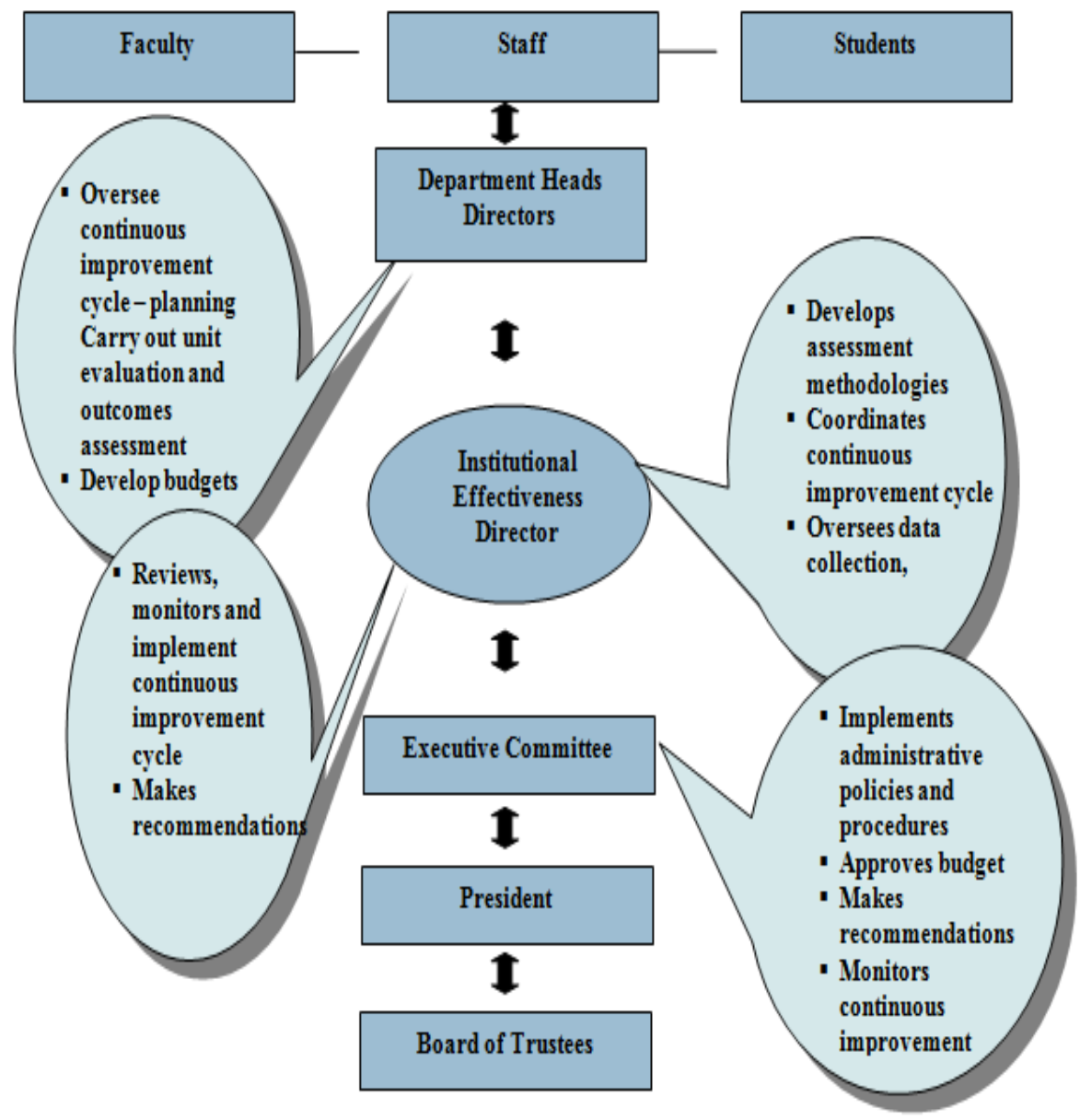

Figure 3. Organization chart for the institutional effectiveness model.

After building an IE infrastructure, the institutions need to set up a strategic plan. Institutions that have participated in the financial autonomy pilot will have an advantage when implementing the IE process and setting up a strategic plan that aligns the assessment of academic units with the university's resources and budget allocation. Strategic planning outlines a clear path for institutions to achieve their goals and provides clear information to stakeholders (Silver, 2018) [26]. This process enables institutions to identify their strengths, challenges, and opportunities in the planning stage. Strategic planning also must be supported 
with a thoughtful resource allocation process to ensure that university resources are directed toward the achievement of the goal (Powell \& Tedder, 2018) [27].

Finally, to allocate resources appropriately, units must complete all four steps in the Assessment Cycle to provide evidence for financial, human, or infrastructure budget allocation. This research found that not many universities in Vietnam are familiar with the last two steps of this model. However, the institutions need to follow all the steps in the model to gather assessment results for continuous quality improvement. Resources that could help Vietnamese HEIs to implement this model successfully include Assessing Academic Programs by Mary Allen (2004) [4], Assessing Student Learning by Linda Suskie (2009) [11], Assessment Essentials by Trudy Banta (2014) [15], and Using Evidence of Student Learning to Improve Higher Education by scholars at National Institute of Learning Outcome Assessment (NILOA) (2015).

\section{Conclusion}

This study examined Vietnamese key educators' perceptions about the potential of implementing a U.S. regional accreditation output standard, Institutional Effectiveness (IE), to address output in the current set of accreditation standards in Vietnam higher education. This research has tried to answer three questions: the participants' perceptions about the higher education accreditation standards, the implementation of IE process and Assessment Cycle, and suggestions for the implementation. All participants agreed there is an absence of output-oriented standards in Vietnam higher education accreditation standards. They also believed the implementation of an IE process and Assessment Cycle beneficial to improve the role of accreditation on ensuring the quality assurance of higher education institutions. Since these ideas are new and weak in Vietnam higher education, participants recommended having more financial autonomy for higher education institutions to practice strategic planning and have capacity to allocate budget and resources based on the assessment results. This research also tried to make some recommendations to the MOET, centers for accreditation, and offices of quality assurance to facilitate the implementation of IE. Although this research is not generalizable beyond Vietnam, educators in other countries that are developing their higher education accreditation systems may be able to use the results of this research to inform their efforts. When implementing this research, the readers might consider two limitations. Although each of the six regional accrediting agencies in the U.S. share similar expectations of IE, they have their own language to address IE in its own standards. Hence, the suggestion of IE standard for Vietnam higher education accreditation only represents the language of the Southern Association of Colleges and Schools Commission on Colleges (SACSCOC). Also, most of the study's participants are involved in assessment and accreditation activities; therefore, it lacks the voice of faculty and staff who are not in favor of assessment and accreditation.

Appendix A: Semi-structure Interview Questions

1. What is your role in accreditation?

2. How long have you been working in quality assurance in Vietnam?

3. What is your opinion about Vietnamese national set of quality assurance standards for higher education?

4. What are the issues that Vietnam has encountered with its set of quality standards for higher education?

5. What is your expectation of accreditation in Vietnam higher education?

6. Introduce some information about the components of Institutional effectiveness cycle in SACSCOC Comprehensive Standard 3.3. State the focus of this research is on 3.3.1.1 and 3.3.2. How is Institutional Effectiveness 
addressed in Vietnam national set of quality assurance standards?

7. Provide experience of Southwest University to work on 3.3.1.1 and their suggestions for a developing country to work on it. What do you think about adapting 3.3.1.1 in Vietnam set of quality assurance standards? What are the challenges Vietnam may encounter? How to adapt it?

8. What are Vietnamese educators' suggestions to adapt the standard of Institutional Effective in Vietnamese national set of quality assurance standards?

\section{References}

[1] Hayden M \& Lam Q T (2010). Vietnam's higher Education System. Reforming higher education in Vietnam: Challenges and Priorities. 15-31.

[2] Pham, Duy. (2014). Vietnam: New legislation and future possibilities. International Higher Education. 74. 27-28.

[3] Nguyen, Kim. D, Oliver, D.E., \& Priddy, L.E. (2009). Criteria for accreditation in Vietnam's higher education: Focus on input or outcome? Quality in Higher Education. 15 (1). 123-134.

[4] Nguyen, Thi Khanh Trinh (2013). The strengths of Vietnam Higher Education accreditation standards. Conference proceeding on Quality assurance standards for higher education in Vietnam: Implementation issues and solutions. pp.48-56.

[5] Nguyen, Huu Cuong, Evers, C \& Marshall, C (2017). Accreditation of Viet Nam's Higher Education: Achievements and Challenges after a Dozen Years of Development. Quality Assurance in Education. 25 (4), 475-488.

[6] Center of Educational Accreditation (2014). [The establishment of center of accreditation in VNUHCM]. Retrieved from http://cea.vnuhcm.edu.vn/quyet-dinh-thanh-laptrung-tam-kdclgd-dhqg-hom_p1_1-1_2-1_3617_4-76_9-2_11-10_12-1_13-11.html

[7] Nguyen, Duc Chinh. (2013). The Vietnamese set of quality assurance standards for higher education: Issues and Solutions. Conference proceeding on Quality assurance standards for higher education in Vietnam: Implementation issues and solutions. 91-97.
[8] Do, Huong Lan (2013). Mot so de xuat nham hoan thien cac tieu chuan danh gia chat luong giao duc cua truong Dai Hoc Viet Nam tren co so nghien cuu so sanh bo tieu chuan danh gia cua Viet Nam va Lien Bang Nga. Conference proceeding on Quality assurance standards for higher education in Vietnam: Implementation issues and solutions. MOET project. Code: B2012-08-12], 165-178.

[9] Le, Duc Ngoc \& Sai, Cong Hong (2013). Assessing the inappropriateness of the set of quality assurance standards for higher education in Vietnam and the reasons. Conference proceeding on Quality assurance standards for higher education in Vietnam: Implementation issues and solutions. 143-157.

[10] Vo, Sy Manh (2013). Some shortcomings in the Vietnam set of quality assurance standards. Conference proceeding on Quality assurance standards for higher education in Vietnam: Implementation issues and solutions. 158-164.

[11] Suskie, L. (2009). Assessing student learning. A common sense guide ( $2^{\text {nd }}$ Ed.). Jossey-Bass: A Wiley Imprint.

[12] Eaton, J. (2007). Institutions, accreditors, and the federal government, redefining their "appropriate relationship." Change, 39(5), 16-23.

[13] Suskie, L. (2015). Five dimensions of quality: A common sense guide to accreditation and accountability. Jossey-Bass: A Wiley Brand

[14] Gaston, P.L. (2014). Higher education accreditation: How it's changing, why it must. Sterling, VA: Stylus.

[15] Banta, T. W. (2004). Hallmarks of effective outcomes assessment. San Francisco, CA: Jossey-Bass.

[16] Anderson, H. M., Moore, D. L., Anaya, G., \& Bird, E. (2005). Student learning outcomes assessment: A component of program assessment. American Journal of Pharmaceutical Education, 69(2), 256-268.

[17] Ewell, P. T. (2009, November). Assessment, accountability, and improvement: Revisiting the tension (NILOA Occasional Paper No.1). Urbana, IL: University of Illinois and Indiana University, National Institute for Learning Outcomes Assessment.

[18] Prochnow, M. E. (2011). On reaching proficiency: A case study of outcomes assessment success at a California community college. (Dissertations). California State University, Fresno. (Order No. 3473418). Retrieved from http://search.proquest.com/docview/895096456?a countid=7098. $(895096456)$. 
[19] Hoefer, M.T. (2015, July). The ABCs of institutional effectiveness. Pre-conference workshop at SACSCOC Summer Institute, Orlando, Florida.

[20] Allen, M (2004). Assessing academic programs in higher education. Bolton, MA: Anker Publishing Company, INC.

[21] Glesne, C. (2011). Becoming qualitative researchers: An Introduction (4th Ed.). Boston, MA: Allyn \& Bacon.

[22] Merriam, S (1998). Qualitative research and case study applications in education. San Francisco: Jossey-Bass Publications.

[23] Grbich, C. (2013). Qualitative data analysis an introduction. Thousand Oaks, CA: Sage Publications VNU-HN- College of Economics, 2017.
[24] Middaugh, M. F. (2007). Creating a culture of evidence: Academic accountability at the institutional level. New Directions for Higher Education, (140), 15-28. doi:10.1002/he.277.

[25] Voluntary System of Accountability (VSA). About the VSA. Retrieved from http://www.voluntarysystem.org/

[26] Silver, K. (2018). Getting Started with Strategic Planning. HLC Annual Conference. Chicago, Illinois. Retrieved at http://download.hlcommission.org/annualconferen ce/2018/AC18_ProgramBook_INF.pdf

[27] Powell, B. and Tedder, W. (2018). Linking Assessment, Planning and Budgeting for Resource Allocation Decisions. HLC Annual Conference. Chicago, Illinois. Retrieved at http://download.hlcommission.org/annualconferen ce/2018/AC18_ProgramBook_INF.pdf.

\title{
Cải tiến bộ kiểm định chất lượng Việt Nam theo tiêu chí hiệu quả toàn trường của kiểm định vùng $\mathrm{SACSCOC}$
}

\author{
Phạm Thị Tuyết Nhung \\ Truờng Đại học Ngoại Ngũu, Đại học Huế, 57 Nguyễn Khoa Chiêm, Huế, Việt Nam
}

Tóm tắt: Mục đích của nghiên cứu này là tham khảo ý kiến của các nhà giáo dục Việt Nam về tính khả thi khi tích hợp tiêu chí hiệu quả toàn trường của kiểm định vùng SACSCOC Hoa Kỳ vào bộ kiểm định chất lượng giáo dục đại học Việt Nam. Quy trình hiệu quả toàn trường (Lập kế hoạch chiến lược - Lên kế hoạch và đánh giá - Phân bổ ngân sách) và Chu kỳ đánh giá (Chuẩn đầu ra chương trình - Ma trận chương trình đào tào - Các phương pháp đánh giá - Thu thập số liệu - Cải tiến chất lượng) được sử dụng làm công cụ phân tích cho nghiên cứu này. Nghiên cứu định tính sử dụng phỏng vấn để tham khảo ý kiến bảy nhà giáo dục Việt Nam làm việc tại các trung tâm kiểm định chất lượng và văn phòng đảm bảo chất lượng tại các trường đại học Việt Nam. Kết quả cho thấy tất cả những người tham gia đều ủng hộ tích hợp chu kỳ hiệu quả toàn trường và chu kỳ đánh giá vào bộ tiêu chí kiểm định chất lượng giáo dục đại học của Việt Nam. Kết quả nghiên cứu cho thấy quy trình hiệu quả và đánh giá chưa được thực hiện đầy đủ trong bộ tiêu chí kiểm định chất lượng Việt Nam. Các trường đại học Việt Nam chưa có văn hóa lập kế hoạch chiến lược cho toàn trường do ảnh hưởng từ cách quản lý tập trung của Bộ Giáo dục và Đào tạo. Ngoài ra, hầu hết các trường đại học chỉ quen thuộc với hai bước đầu tiên trong chu kỳ đánh giá. Dựa trên kết quả nghiên cứu, tác giả đã đưa ra các kiến nghị cho Bộ GD \& ĐT, Trung tâm kiểm định chất lượng và các trường $Đ H$ Việt Nam để thực hiện chu trình hiệu quả toàn trường và chu kỳ đánh giá.

Tư khóa: Kiểm định chất lượng đại học Việt Nam, Hiệu quả toàn trường, Kiểm định vùng Hoa Kỳ, đánh giá chuẩn đầu ra, tự chịu trách nhiệm và minh bạch. 